Portland State University

PDXScholar

\title{
Métis in Oregon: Intermarriage, Agency, and Religion in French Prairie, 1830-1840
}

Annie B. Amsden

Portland State University

Follow this and additional works at: https://pdxscholar.library.pdx.edu/honorstheses

\section{Let us know how access to this document benefits you.}

\section{Recommended Citation}

Amsden, Annie B., "Métis in Oregon: Intermarriage, Agency, and Religion in French Prairie, 1830-1840" (2019). University Honors Theses. Paper 734.

https://doi.org/10.15760/honors.752

This Thesis is brought to you for free and open access. It has been accepted for inclusion in University Honors Theses by an authorized administrator of PDXScholar. Please contact us if we can make this document more accessible: pdxscholar@pdx.edu. 
Métis in Oregon: Intermarriage, Agency, and Religion in French Prairie, 1830-1840

\section{by}

Annie Amsden

An undergraduate honors thesis submitted in partial fulfillment of the requirements for the degree of

Bachelor of Science

in

University Honors

and

Anthropology

Thesis Adviser

Douglas Wilson, Ph.D.

Portland State University 
Introduction

Interpreting agency among historical peoples is difficult, especially when the individuals in question hold marginalized identities. Illiteracy and oppression forces Indigenous American people into European and Euro-American narratives. This predicament is further complicated when exploring motives of Native American women who were oppressed uniquely due to their intersecting identities. However, by listening to Indigenous anthropologists and deconstructing harmful narratives, the agency of Indigenous peoples can be better ascertained and appreciated.

I was born in Salem, Oregon and grew up in a bend of the Pudding River, a body of water marking the eastern border of the French Prairie in Oregon. I attended the St. Paul Rodeo, visited Oregon City, and walked through pioneer cemeteries. As a white, second generation colonist, I was unknowingly immersing myself in a lopsided Oregon history. So, when I learned of people who lived in the Pacific Northwest (PNW) prior to the mid-19th-century American expansion, I was very intrigued. It is a misconception that the history of the PNW is shallow or recent. Centuries, if not millennia, of human history are evident here.

I first came to this topic due to my intersecting interests in Oregon history, colonialism, and feminist theory. In this thesis, I argue that choices made by the Métis community in French Prairie, Oregon regarding their relationships with Methodist and Catholic missions were largely pragmatic. However, I also place these pragmatic choices into a feminist framework that shows how agency plays out in a colonial setting and exemplifies how scholars can study Indigenous women's agency without unfairly disparaging or over-politicizing them. 
In the following pages, I flesh out the circumstances of French Prairie life for a community of French Canadian fur trade retirees and Indigenous women and argue that their agency played out in constrained and practical ways. I first explain "pre-contact" French Prairie and the Indigenous groups that lived in the PNW prior to any Euro-American settlers, the fur trade's origins and influences in the region, and the ensuing American Expansion that brought disease, religion, and varying groups of Euro-Americans. Then, I explain past and present definitions of agency and colonialism, the characteristics that made 19th-century Oregon a colonial prospect, and the theory I will use going forward. I finally argue that the Métis community made pragmatic choices and situate their actions within a larger system of colonialism.

Contextualizing 19th Century French-Prairie

To understand the choices that French Prairie residents made, it is essential to first acknowledge the social, biological, and institutional entities that surrounded them.

\section{Geography}

In the following sections, I will refer to places in Oregon that may not have the same meaning in modern contexts. First, the Pacific Northwest (PNW) refers to British Columbia, Washington, Oregon, and parts of Montana, Idaho, and Wyoming (Barman 2014). Oregon Country is primarily an American term for the same area, whereas the British Hudson's Bay Company referred to the area as the Columbia District. French Prairie is an area in the Willamette Valley that is bordered by the Willamette River, Pudding River, and Lake Labish. 
Butteville, St. Paul, St. Louis, Champoeg, and Gervais were the five major cities of the French Prairie in the 1800s (Jetté 2015).

Indigenous communities viewed the land differently. Whaley (2005) uses the term Ilahee to loosely refer to Oregon. However, instead of defining their homeland as limited by landmarks or properties, Indigenous people situated themselves within the large network of social ties and spiritual connections to specific places (Whaley 2005). As is made clear by the previous distinctions, how we conceptualize Oregon geographically is dependent upon time and cultural perspective.

\section{“Pre-Contact” Indigenous Landscape}

Though this thesis does not directly engage with Native American groups before the 1830 s, it is essential to understand that a thriving population of people lived in what we now call the Pacific Northwest. The history of these communities could, and has, filled hundreds of pages. In this section, I will briefly touch on the distinguishable communities that lived in the Pacific Northwest and the ways in which their views contrasted with incoming Euro-Americans. Prior to the late 1790s, Oregon Country was relatively untouched by Euro-American colonialism. While the Native Americans in this area were aware of colonists in the East, they had yet to experience the full displacement and devastation that colonialism had caused elsewhere. The Indigenous population of the PNW was composed of many communities who spoke different languages and held different customs but ultimately interacted and formed a larger network of trade and cultural exchange. Whaley (2010) describes this shared land, resource use, and culture as Illahee, a Chinook word meaning land, soil, or home. What Euro-Americans described as "Oregon," Native Americans conceptualized differently. Native Americans in Oregon Country were less 
attached to property and land but maintained a strong sense of place and stewardship (Whaley 2010).

For the purposes of this thesis, I will divide the Native communities into coastal and inland groups. Coastal communities include the Chehalis, Chinook, Clallam, Clatsop, Cowichan, Cowlitz, Kalapuya, Klickikat, Kwakiutl, Kwantlen, Nanaimo, Nass, Nisqually, Saanich, Snohornish, Songhees, Stikine, Tongas, Tsimshian, and Umpqua (Barman 2014, Jetté 2015). Inland communities include the Carrier, Cayuse, Colville, Cree, Flathead, Iroquois, Nez Perce, Okanagan, Pend d'Oreille, Shoshone, Shuswap, Snake, Spokane, and Walla Walla (Barman 2014, Jetté 2015). Coastal Native Americans are commonly associated with having expendable resources and therefore highly stratified social structures whereas inland communities were less stratified (Barman 2014). Though Indigenous people in the region did not experience property and place in the exact same way as Europeans and Euro-Americans, it is important to recognize that the specific group who lived in what is now considered French Prairie were the Ahantchuyuk - also called French Prairie Indians or Pudding River Indians, a band of the Kalapuya.

It is equally important to recognize the social structures that existed prior to direct European contact. Extensive trade and social networks existed between communities, and the earth was heavily modified by Native Americans. The trails that early expeditions used were created and used by Native Americans. Additionally, explorers required the help of Native Americans to traverse the land. Much of the fertile ground that attracted colonists was tended to by local communities by anthropogenic burning and other forms of resource maintenance (Boyd 1999). The earliest interactions with European colonists were indirect. Introduction of horses 
from the South and the spread of diseases hit the Native communities before explorers and settlers did. By the early 1800s, both American and British (spurred by American advances) expeditions had been sent to Oregon Country.

Fur Trade and French Canadians

The first expedition by Europeans to the PNW occurred in the late 18th century. In 1793, Alexander Mackenzie, a North West Company (NWC) representative, travelled with six French Canadian men across middle Canada in search of fur trade opportunities. While no fur trade came from this expedition, it allowed for future ventures into the Pacific Northwest (Barman 2014). It wasn't until 1804 that competition between the United States and Britain ensued. The American Lewis and Clark expedition (1804-1806) made clear that both the U.S. and Britain were interested in the PNW. From 1805 to 1807, the NWC executed two expeditions to seek the mouth of the Columbia River. The NWC was a British company based in Montreal, Canada. Simon Fraser, who had been ordered to follow a northern route, reached the Pacific coastal region but failed in his search for the mouth of the Columbia River. David Thompson, however, was sent on a southerly route. He and a clerk along with six French Canadians found the source of the Columbia River and established the Kootenae House in 1807. With the help of French Canadians and Native Americans, he was able to establish a trading post for the NWC. In 1810, American Wilson Price Hunt led an overland expedition from New York to the newly forming Fort Astoria in Oregon Country. The Pacific Fur Company (PFC), an American fur company that would eventually dominate the market, had tasked him with recruiting trappers along the way. Most of the trappers who remained with him through the whole expedition were French 
Canadian, a third of whom were still employed when the Hudson Bay Company (HBC) absorbed the NWC (Barman 2014).

The War of 1812 between Britain and the United States resulted in the sale of Fort Astoria to the NWC. At the end of the war, both countries agreed that they would occupy Oregon Country jointly. However, in 1821, the British government gave the British Hudson Bay Company a 21 year monopolistic over fur trade in the PNW. Early on, the HBC was largely composed of French Canadians, Iroquois, and mixed or indigenous workers. Though these men made up most of the workforce, British or Euro-American men overwhelmingly held the positions of power and were afforded more privileges (Barman 2014). John McLoughlin, born to French-Canadian and Scots-English parents, served as head of the Columbia department of the HBC from 1824 to 1845 . McLoughlin played a major role in shaping the European settlement of Oregon Country. Whether the fur trade ventures in the PNW were American or British in origin, they shared one commonality: French Canadians. These men facilitated the expeditions, stuck by the endeavors, and made up a bulk of the workforce upon arriving at the fur trade posts.

\section{Contested Territory and American Expansion}

Until the Oregon Treaty of 1846, multiple imperialist forces had their eyes on Oregon Country. Following the Treaty of Ghent, the United States and Britain argued over the American-Canadian border. British officials had agreed to own the land north of the 49th parallel on the condition that they also maintain partial ownership to the mouth of the Columbia River. Americans refused. In 1818, both nations agreed to jointly occupy the land for ten years. This agreement would be renewed twice. Russia and Spain had officially withdrawn by the mid-1820s, leaving Britain and the United States to squabble over the land. Fur traders, backed 
by larger political forces, trickled into the PNW at the start of the 19th-century, marking the first wave of Native displacement and death. In the 1830s, Methodist, Catholic, and Presbyterian missionaries travelled to the region in the hopes of converting Native Americans (Thomas 1993).

Though the "Oregon Trail" refers to a specific route Euro-Americans took to settle in Oregon Country, it represents a popularized narrative of brave Americans taming the "Wild West." American migration to the region boomed from 1843 to 1844 . Thousands of Euro-Americans squatted on Indigenous lands in hopes that the U.S. government would later grant them the land, which it often did (Whaley 2005). Upon arriving in Oregon, many immigrants were often sold or loaned supplies by John McLoughlin because few other resources existed (O’Hara 1917). From 1843 to 1851, over 10,000 Euro-Americans had travelled west to claim land in Oregon Country (Whaley 2005).

\section{Disease}

Fur traders, missionaries, and Euro-American settlers brought unfamiliar diseases into Oregon. While some Europeans and Euro-Americans did die from disease, Native Americans overwhelmingly bore the brunt of the destruction due to their lack of biological immunity and unfamiliarity with the illnesses. Disease is difficult to study in historical contexts due to the nuances of diagnoses and the overwhelming amount of death. Robert $\mathrm{T}$. Boyd has performed the bulk of research on introduced diseases in the PNW (1985). In the 1770s, from 1800 to 1801, and again from 1836 to 1837, smallpox plagued Native Americans in Oregon Country. Other diseases such as typhus and influenza were also introduced and wreaked havoc, though to a lesser extent. Sexually transmitted infections, often transferred between European men and Native American women, also caused problems in the sexualized setting of colonial Oregon. 
Even when the initial disease did not kill the host, secondary complications such as pneumonia could.

The disease that seems to have been the most destructive has now been identified as malaria. The "intermittent fever" caused fever and chills, headaches, excessive sweating, and thirst. Native Americans, unfamiliar with the disease, often used traditional sweating and cold water dipping to combat the illness. These types of treatments proved disastrous for malaria. Additionally, the disease often resurfaced yearly in the late summer months, extending the suffering to years. By the 1820s, quinine was known amongst Euro-Americans to cure malaria, but Native Americans did not have access to this medicine. Boyd (1985) hypothesizes that Euro-Americans did not die as frequently from malaria not because of built immunity, but due to access to medicine.

Vibert (1995) claims that prophetic movements within Indigenous communities of the early 19th-century Columbia Plateau appeared in response to early smallpox epidemics. Native Americans viewed the disease as evidence of spiritual unrest. Neither Indigenous people nor Europeans understood disease entirely during the 1800s. Also, as Vibert (1995) suggests, Native people early on did not necessarily associate the diseases with European invaders. The effects of disease were devastating to Indigenous communities. In the Lower Columbia area between 1805 to 1840 , an estimated $86 \%$ of the total population had died, most of them from disease. The population had gone from almost 18,000 to less than 3,000 over the course of 35 years (Boyd 1985). These estimates are likely conservative. In addition to initial deaths, Native communities suffered from increased infertility caused by several of the diseases, community and cultural destruction, and spiritual dismay. Also, Western scientific thought of the era suggested that 
Native Americans died due to their biological inferiority. This only served to fuel the self-righteous expansion that would continue throughout the 19th-century.

\section{Missions}

Though there were no formal European religious organizations in Oregon Country prior to the 1830s, religion and spirituality were important for all populations in the region. As stated previously, Indigenous peoples placed high importance on spirits. Their involvement with spirituality was only intensified by increasingly common plagues and diseases (Whaley 2005). This is an oversimplification of PNW Native Americans' beliefs, but for this thesis, it is only necessary to understand that Native Americans in Oregon Country had their own religious and spiritual beliefs prior to European missionization. Also, Indigenous people tended to integrate new religions into their own. This contrasts with the image of the impressionable Native American that missionaries expected (Thomas 1993). French Canadians in the fur trade also maintained their religious beliefs despite a lack of formal religious institutions. For example, Catholics in the fur trade were known to sing hymns and pray (Barman 2014). In contrast, David Thomas (1993) states that many "Mountain Men" rejected religion and told the Native Americans that there was no God. He claims that the inability to relate to Eastern Christianity could have motivated these men to head west (Thomas 1993). Many Americans viewed Oregon Country as a lawless land devoid of religion and morals. However, this was untrue. Native Americans engaged in spiritual rituals and had complex belief systems. French Canadian fur trappers who had no permanent religious presence kept up their Catholic beliefs.

In 1834, French Canadian settlers petitioned for a Catholic presence at French Prairie. It would be the first of several letters sent to eastern Canada (O'Hara 1917, Thomas 1993, Jetté 
2007, 2015). There were too few resources to send priests at that time. In that same year, American Methodist missionaries were sent to the Willamette Valley. The arrival of missionaries Jason Lee and four others was spurred by a nationwide call for religion in the Far West (Thomas 1993). Beginning in the 1790s, the Second Great Awakening had renewed an American fervor for Evangelism. This desire to convert Native Americans mobilized missionaries and ultimately funded the expeditions to Oregon Country (Whaley 2005; Olson 2014). Though Jason Lee and the other missionaries had primarily wished to convert Western Native Americans, they were likely advised to set up in French Prairie rather than seek out the Native Americans directly (Thomas 1993). The missionaries found much of the fur trade society unsavory. They disapproved of the way the French Canadians worked on the Sabbath, their occasional alcohol consumption, and their informal marriages (Thomas 1993; Jetté 2007). The French Canadians and their Native wives, who lived close to them, viewed the missionaries with a similar disdain. However, the settlers also assisted the missionaries and ultimately welcomed them into their community (Thomas 1993). The missionaries' neighbors attended church when they could, were married formally by mission representatives, and participated in temperance movements (Jetté 2007, 2015). By 1840, there were approximately 70 individuals working with the Methodist mission in French Prairie (Thomas 1993). To summarize, the relationship between Methodist missionaries and French Prairie families was tense at best.

In 1835,1836 , and 1837, the Catholic settlers sent the Catholic clergy increasingly urgent requests for clergymen to be sent to their community. Jetté $(2007,2015)$ argues that the arrival of Presbyterian missionaries in 1836 pressured the Catholics to send the last letters to the Catholic church out east. In that same year, the HBC agreed to lend Catholic clergymen boats to travel to 
the Columbia District and plans were set to send missionaries west. French Prairie community members had started constructing a log building for church services in preparation for the mission's arrival. When Father Francis Norbert Blanchet and other missionaries arrived at the HBC in 1838, several community members greeted them (O'Hara 1916; Jetté 2007, 2015). On January 6th, 1839, Father Blanchet blessed the church they had made under the name of St. Paul. Community members gathered at the church for the first several days that Blanchet spoke, those living further away tenting in the churchyard. In the following weeks and months, Blanchet "properly" married common-law partners, baptized children, and instructed the community in Catholic chants, prayers, and sacraments. Some of the marriages performed had already been sanctified by the Methodists, which offended the Methodists. Additionally, Blanchet instructed the French Prairie community members to stay away from the Methodists with whom they had previously cooperated (Thomas 1993).

Both American Methodists and Canadian Catholics faced unforeseen difficulties in Oregon Country. By the time they had arrived, much of the Native population the Methodists had wished to convert had died by disease. Ironically, the era of the late 18th and early 19th centuries not only ushered in a revitalized Evangelism, but it also saw the rise of scientism. This rise in "scientific" thought promoted racialism and justified colonial destruction of Native peoples. The seemingly endless death of Native Americans from disease combined with their dissent for the Methodist missionaries led Jason Lee to believe that Native Americans were destined to die out due to their biological inferiority (Whaley 2006). Moreover, the Methodists struggled to make a life on the frontier and often complained of how little time they had for prayer. The Catholics, in turn, also faced dismal odds in the PNW. Father Blanchet himself spent 
a considerable amount of time with Native Americans, lamenting at the death and dismay he faced regularly (Thomas 1993). Though the Methodists and Catholics tolerated each other, their relationship was ultimately antagonistic. This reflected the tension between the two denominations elsewhere in the United States. By the 1840s, Oregon had multiple religious institutions. Methodism remained dominant for the years to come, especially in the wake of the ensuing American expansion. However, the Catholic mission had a lasting effect on the French Prairie community.

\section{Community of Focus}

In this paper, I focus on a community of French Canadian retired fur traders and Native or Métis women who they married. While the community was few in numbers, their impact was large and lasting. Married French Canadian men and Native women shaped the political and physical landscape that enticed Americans to move west. I have chosen to focus on this group because Melinda Marie Jetté (2007) argues that this specific community's call for a Catholic presence in their small town was an act of agency. Her work is largely why I focused on this community.

At the end of their contracts with the HBC, French Canadian fur trappers were to be sent back past the Rockies. However, many wanted to stay in Oregon Country. According to Barman (2014), French Canadians decided to stay for a multitude of reasons. Many of the men had little waiting for them at home. Some men had parents, family members, and wives, but many had lost touch with anyone they had known in the East. Because many French Canadians were illiterate and poor, they had few resources to send mail and depended upon literate representatives to read and write for them. Moreover, any money that was sent home to their family members made it 
more difficult for them to return at the end of their contracts. In many ways, fur traders were stuck in the Company. However, many men also stayed for more personal reasons. The fur trade in the PNW was largely composed of French-speaking Canadians of similar ages. Often, they were employed by HBC for many years together and had forged relationships with each other and with local Native communities. French Canadian fur trappers had a distinct culture. Perhaps most importantly, many had married and started families with Native American and Métis women (Barman 2014).

These Native and Métis women were from diverse groups including the Kalapuya, Chehalis, Clatsop, Kwakwaka'wakw, Shushuwap, Chinook, Clackamas, and Okanagan communities (Jetté 2015). Native Americans in the Pacific Northwest were vital in developing the fur trade. Relationships between Native women and fur trade men were political, economic, and/or exploitative arrangements. However, Native women sometimes initiated these unions. French Canadian and Native families formed in the French Prairie of Oregon as early as the 1810s. Native wives were principal decision makers who shaped their Métis community along with their husbands. Both Native women and French Canadian men had grown up in the fur trade and therefore often spoke Chinook Wawa, a hybridized language associated with the fur trade.

Initially, the HBC disapproved of their retired fur trappers settling in the region. They feared that the responsibility they had over them would be a hindrance. However, as competition between Britain and the United States for Oregon Country rose, John McLoughlin supported those who decided to stay in the area. He and other HBC officials viewed the settling of French Prairie as staking an ideological and physical claim on the land. Members of the newly formed 
community relied on the HBC for supplies that made settling in the area feasible (Barman 2014). It is difficult to establish how many people lived within this loosely bound community. Barman (2014) states that the HBC recorded 400 unions between some 330 French Canadian men and 400 Native women up until 1858 . She also states that this number is likely inaccurate due to marriages that ended before the HBC took over in 1821 or were performed by the Catholic mission following 1838 (Barman 2014). While this proposed number is already small, in this thesis I focus even more narrowly on a particular group of people. I am particularly interested in a group of settlers who, in the 1830 s, engaged with Christian missions. According to a letter sent by the community in question, ten French Canadian men and eleven Native (and one Métis) women lobbied for a Catholic presence in French Prairie (Jetté 2007, 2015).

Agency and Colonialism

Agency and colonialism interact in interesting ways. In this section, I will explain why the occupation of Oregon Country by competing national forces and the subsequent settling were colonial acts, discuss how agency can be studied in colonial settings, and outline a model of understanding agency that can be applied to Indigenous women.

\section{Colonialism in Oregon Country}

According to Whaley (2005), colonialism is the “...ground-level reality of imperialism: actions, local decisions, and their consequences, which can defy or support an empire..." Imperialism in this definition is the process of political decisions and systems that enable expansion. In "Oregon, Ilahee, and the Empire Republic: A Case Study of American Colonialism, 1843-1858," Gray Whaley argues that westward movement in the mid-1800s 
should be considered colonialism, rather than American expansion (2005). In this thesis, I often refer to the colonization of Oregon Country as American expansion, but still hold that it is a form of colonialism.

Expansion into and fur trading within Oregon Country was colonialism masked as manifest destiny. The fur trade marked the first wave of colonization - an exploitation of labor and resources. The settling of retirees was the first invasion of Euro-Americans that planned to stay in Indigenous lands. In the creation of Oregon as an American state, the Indigenous communities were largely displaced and killed. Though many Native Americans died from diseases unknowingly transferred from Euro-Americans, violent acts toward Native people were commonplace and essential to the imperial enterprise. This exploitation and abuse of Native populations is characteristic of colonies. Additionally, there existed “...internationally contested territory, entrepreneurship, Christian [proselytization], settler-colonialism, and national incorporation" (Whaley 2005). A characteristic of colonialism is that violence and expansion are systematized and institutionalized. In Oregon Country, business enterprises such as the fur trade served as the first wave of colonists. Missions came in second, masked as an effort to "save" Native Americans. Both Britain and the United States were represented by the Catholic and Methodist missions, respectively. The last stages of colonialism in Oregon were the influx of American settlers and the assimilation and displacement of Native Americans. Various government institutions forced Native communities off their lands with treaties and took their children to boarding schools. Finally, in 1859, Oregon was granted statehood and incorporated into the United States. The stages of colonialism in Oregon Country occurred over approximately 60 years. The deliberate speed of colonization in addition to the death of Native Americans from 
genocide and disease allowed the United States to instill the narrative that westward expansion was inevitable and justified. French Prairie, Oregon and its settlers and residents should be viewed in a colonial framework because although American expansion has not traditionally been considered colonialism, it fits the definition.

Agency in Colonial Settings

Agency refers to choices and actions made by individuals that are at least partially independent from cultural orthodoxies. Understanding agency in colonialism is reliant upon recognizing the interplay of power and decision-making. Historically, agency has been reserved for European men. Anthropologists of the first half of the twentieth century assumed that white men acted of their free will, reflecting the free enterprise mindset of the time. In early studies of American colonialism, decision-making was reserved for white men and other players were considered inconsequential. Roles of women, especially Native women, were supporting and submissive. By the 1960s, anthropologists began to question this assumption. Second-wave feminism evoked studies of patriarchal subordination of Indigenous women but ignored their agency. Later, intersectional feminists began to acknowledge that Indigenous women made choices in order to maintain power in colonial settings (Spencer-Wood 2016). However, the roles given to Indigenous women are often limited and do not reflect how they maintained and negotiated their Native identities.

Agency and Indigenous Women

Historically, Native women have been viewed as cultural brokers. Whether through "intermingling" with white men or as guiding explorers through unfriendly Native territory, these women have been reduced to submissive aids for European male colonists. While 
academics have recently shifted in this view, popular media and narratives of Native women have not. Sacagawea is one of the most famous examples of a "cultural broker." According to legend, she helped Lewis and Clark pass through the uninviting Oregon Country and touch the Pacific. In reality, she was a Lemhi Shoshone woman who had married a French Canadian man and served as a translator from 1804 to 1806 for a variety of reasons (Barman 2014). This view of Sacagawea only places value onto her due to the aid she offered Americans. It assumes that she acted in this way to promote the United States' claim on the land when her motivations were likely diverse and not entirely within her control. Viewing these women as cultural brokers also implies that Native women are less "Native" than their men counterparts and that they lose their Indigeneity after they marry white men. Also, placing a label of "cultural broker" places an undue political burden onto Native women who, in many situations, were only striving to survive.

Intermarriage as a form of agency on the part of Native women has been explored by Sylvia Van Kirk. She has written on the importance of intermarriage in the western fur trade (Van Kirk 1983, 2002; Barman 2014). Van Kirk (2002) writes that much of the motivation for intermarriages between Native women and white fur trade workers came from Native communities. David Peterson-del Mar (1995) argues that Celiast Smith, a Chinookan woman of the Lower Columbia, used multiple marriages to advance herself in the rapidly changing society. The daughter of a Clatsop Chief, she apparently was business savvy and attractive. She married (or was married to) Basile Poirie in the early 1820s. Reportedly, this was an unhappy and abusive marriage. In 1833 or 1834, she left her husband, perhaps influenced by John 
McLoughlin's urging, and married Solomon Howard Smith (Peterson-del Mar 1995). Smith was a wealthy and influential pioneer in Oregon and Celiast improved her status by marrying him.

Celiast, among other women, participated in fur trade society in more than domestic ways. They often traded, proving themselves forces to be reckoned with. According to Barman (2014), fur trade workers "took Indigenous women seriously." Also, when married to French Canadian men, they played a role in decision-making for their families (Jetté 2007, 2015; Barman 2014). While intermarriage $i s$ a way that Indigenous women performed their agency, the overreliance on this expression of agency is problematic. As with Celiast Smith, circumstances surrounding marriage and power were complicated and not entirely within the woman's control. She was beaten and otherwise abused by her first husband and likely sought safety over an increased social status. Native women did sometimes marry colonists to further their social status and gain power, but to assume they did so for those reasons alone dismisses the oppression they experienced. Additionally, marriages between Indigenous women and white men were anything but stable. Men would sometimes take multiple wives in different places as they travelled for the fur trade, often abandoning their partners. When Methodists, and later Catholics, came to French Prairie, they did not respect these "common law" or "country" marriages and insisted that they be remarried properly (Jetté 2007, 2015). Even when marriages lasted, men could abuse their wives with little fear of lawful repercussions. Therefore, to classify marriage as a singular thing that Native women did to raise their social status oversimplifies the insecurities of fur trade unions in the Far West.

\section{Constrained Pragmaticism}


Nassaney (2019) argues that Native Americans and French colonists at Fort St. Joseph in Michigan utilized expedient and pragmatic strategies of material integration and modification in the seventeenth and eighteenth centuries. Materialism in archaeology rests on the assumption that creation, modification, and integration are reflective of cultural and social changes. He states that colonial forts were politically charged locations in which "...identities were negotiated, contested, transformed, and enacted." He criticizes the metissage narrative that he and others had previously supported - that is, the idea that French colonialism was "gentler" because ethnic lines were blurred. Instead, he proposes that even in the face of racial mixing, individuals maintain their original identities. Also, he stresses that the drive for survival is a predominant reason people adapt to new situations and integrate new materials. While this theory is specifically related to interpreting physical artifacts, its implications apply to intangible actions as well. I use this theory to argue that Indigenous women and French Canadian men made pragmatic decisions when dealing with Christian missions. Their decisions may have had ideological implications, but they most likely acted in ways that would ensure their survival and offer them tangible benefits. Additionally, the French Canadian husbands and Native American wives maintained distinct identities and while they likely made decisions together, their motives may have been different.

In my analysis of the Métis community's choices, I also use Suzanne M. Spencer-Wood's (2016) model of patriarchal colonialism. In her article "Feminist Theorizing of Patriarchal Colonialism, Power Dynamics, and Social Agency Materialized in Colonial Institutions," she argues that colonial and post-colonial studies that do not consider gender exclude the inherent patriarchal and exploitative structure of colonialism. She claims that what she calls "feminist 
intersectional diversity theory" arose from third-wave feminism. Feminist intersectional diversity theory claims that an interplay of identities such as gender, race, class, age, etc. affect how much power and agency an individual has in a particular society (Friedan 1993; Lorber 2001; Spencer-Wood 2016). Intersectionality, a term coined by feminist theorist Kimberlé Crenshaw (1989), is important while studying agency in colonial settings because "[c]olonized women suffer the most oppression from interlocking sexism, racism, and classism" (Spencer-Wood 2016). This interpretation of power relations in colonies allow for a nuanced view of power. Rather than a situation in which European, high-class men have all the power, she argues that relationships were more heterarchical. This is not to say that colonists were not the overarching oppressor, but that power in colonialism is much more complicated than originally assumed. She identifies three types of patriarchal colonialism: sexual, economic, and domestic. Patriarchal sexual colonialism is the systematic abuse of colonized peoples, usually women. This includes rape and assault, intermarriage, and repression of Indigenous sexual beliefs and customs. Spencer-Wood (2016) does not include this, but I also would count colonial powers' control of their low-class white men as a form of patriarchal sexual colonialism, though the brunt of the violence committed was towards colonized peoples. Sexual colonialism is not necessarily related to piety as missions claimed; it is about control. Patriarchal economic colonialism entails disturbance of existing economic systems and exploitation of Indigenous labor. This type of colonialism is patriarchal because it disrupts gender roles and devalues women's jobs, forcing them into low-wage positions. Patriarchal domestic colonialism is the effort, usually by missionaries, to "civilize" Native folks. Generally, an archetype of Western domesticity and values teaches Indigenous women how to behave according to the colonists' standards. Within 
these three types of patriarchal colonialism, social agents hold different types of power: over, under, with, and from. "Power over" is the most obvious form of power. "Power over" is the ability to exert will over another. Typically, this refers to colonists' control over colonized people. "Power under" is usually synonymous with resistance. Under colonialism, colonized folks have the choice to subordinate and/or revolt, among other subtle methods of resistance. "Power with" implies some level of cooperation or collaboration. Often, colonized people will work with oppressors to obtain power in the colonial setting. "Power from" is similar to "power with.” It usually means that Indigenous people glean political or social power by cooperating with colonizers. The distinction between the two types of power is that "power from" applies more to powers gained rather than the process of collaboration.

In my analysis of the French Prairie community's relationships with the Methodist and Catholic missions, I utilize Nassaney's (2019) theory on pragmatic incorporation and identity retention and Spencer-Wood's (2016) model of patriarchal colonialism. In colonial settings, various institutions controlled by the empire exert power over their subjects and force agents to make decisions based on survival and other practical reasons. However, choices made by colonized people are ultimately about "powers": "powers over," "powers under," "powers with," and "powers from." The motivations of French Canadian men are relatively easy to determine as pragmatic from various documents and accounts. However, due to the oppression and forced narratives placed upon Indigenous women, it is more difficult to ascertain their motivations. As the colonial subjects who received the most violent oppression, it is worthwhile to utilize Spencer-Wood's (2016) theory of patriarchal colonialism to better investigate their choices. 


\section{Constrained Pragmaticism}

While I agree that the French Prairie community sought community from their requests for Catholic representation, I also argue that there were other factors that led these people to make these decisions. Not only did the community exert effort in writing to the Catholic church, they also built a church for them prior to their arrival. In colonial settings, individuals make choices pragmatically, negotiating between benefits and identity (Nassaney 2019). Jetté (2007) argues that the call for Catholic clergy in French Prairie was a form of agency. In the following sections, I argue that there were social, spiritual, material/economic, and political benefits to this choice. It doesn't matter whether these benefits were real or perceived.

Between 1833 and 1839, the newly formed Metís community of French Prairie, Oregon interacted with the Methodist and Catholic missions in ways that benefitted them practically. Their limited options in the constrained colonial setting likely forced them to make decisions that seemed contradictory but ultimately offered them social, spiritual, and political benefits. In 1834, French Canadian men, likely with consultation with their wives, petitioned for a Catholic presence in their community. Jetté (2007) remarks that they probably did this due to a need for spiritual and social guidance as well as stable community center and schooling for their growing families. From a spiritual perspective, French Canadians also sought the religion of their youth to raise their own families with. The Indigenous women had come from communities that had been destroyed by death and disease themselves and likely wished for spiritual guidance as well. Politically, having a Catholic church in the community would further legitimize their claim to the land and their partnerships. The Catholic church did not respond to their initial plea in 1834, but that same year a Methodist mission had already set out for Oregon Country. 
Though the Methodists were not exactly what the community had asked for, they welcomed and cooperated with missionaries before the arrival of Catholics. They attended sermons, were married and baptized, and participated in the Methodist-led temperance movement. The mission's establishment of a school and regular church services provided tangible social benefits for the community. Moreover, Christian education and marriage performances served to elevate the wives' statuses in the colonial space. It is also possible that the women benefited from the temperance movement. Traditionally, the temperance movement was related to women's rights in that it dissuaded abuse by their husbands and reinforced women's perceived moral superiority. The mission may not have been Catholic, but the French Canadians were likely grateful for the spiritual guidance. Additionally, cooperating with American Methodists ensured that they would retain fair treatment in the case of increased immigration or missionary presence. However, the relationship between the community and Methodists was contentious at best. While the missionaries spoke British and wished to teach the community to do the same, the French Canadians and Native Americans spoke French or Chinook Wawa. Jason Lee once wrote that often community members would come to his house and hold lengthy conversations with him, of which he could understand very little (Jetté 2007). The missionaries' efforts were also spread thin between the French Prairie community and their original target, the Native Americans. The Methodists also viewed Catholics and Native women with disdain which likely caused tension and social stratification.

Their dissatisfaction with the Methodist mission ultimately led to the French Prairie community's repeated pleas for Catholic representatives in 1835, 1836, and 1837. French Canadians still held hope that their childhood religions would return to their lives. Also, they and 
the Native women likely gained little spiritual benefit from the Methodist sermons due to the language barrier. The French Canadians were inherently tied to the fur trade and the HBC. While their relationships with their superiors at Fort Vancouver were sometimes tense, they had built their community around it. Though there is no evidence that John McLoughlin supported their requests for political reasons, it makes sense that they would usher in Catholic missions who would legitimize Britain's and the fur trade's hold on the area. In 1836, the community built a $\log$ church in hopes that the Catholic mission would come soon. Finally, in 1838, Father Blanchet and other Catholic missionaries arrived in Oregon.

Father Blanchet remained in the French Prairie community for a short time before moving onto Native American territory and rarely visited thereafter, but his impact was lasting. He and the other missionaries advised the community against attending Methodist services, performed marriages that the Methodists had already performed, and spoke to the people daily. At Father Blanchet's request, the community also backed out of the temperance movement due to the nature of Catholic sacraments (Jetté 2015). Tensions between the Methodist and Catholic missions mirrored the conflict between Catholics and other Christians in the United States as well as the conflict between the United States and Britain. The Methodist missionaries attempted to win back the French Prairie community by spreading the book "Awful Disclosures of Maria Monk” by Maria Monk (1836; Thomas 1993). The book was an account by a former nun that accused priests of raping nuns and murdering their illegitimate children. Spreading the literature had an opposite effect than was intended. The illiterate community approached Father Blanchet with the book and obeyed his commands to stay away from the Methodists. Around this same time, a Methodist doctor was accused by Catholics of performing physical examinations on 
Native American wives without their husband's presence or approval (Barman 2014; Jetté 2015).

While the two groups eventually reached a sort of truce, the conflict left the French Prairie community in the crossfire of two colonial forces. The French Canadians' and Native women's decision to remain loyal to Catholic missionaries despite the brevity of Father Blanchet's stay was likely made for social, spiritual, and political reasons. Socially, they had finally received community leaders who spoke French and attempted to learn Chinook Wawa (Jetté 2015). The Catholic presence reaffirmed both the social structures and spiritual beliefs of their settled community. Both French and Chinook Wawa speakers were better able to understand sermons, chants, and prayers, allowing them to gain more spiritual guidance from their time with the missionaries. Especially useful to the Native American women were the Catholic Ladders, or Sahale Sticks, that aided missionaries in the teaching of the Church's history and the history of religion. Because it is hypothesized that Native Americans integrated Christian religions into their existing belief systems rather than adopting them entirely (Whaley 2006), it is reasonable to suggest that the incorporation of religious objects and understandable sermons expanded on Indigenous women's preexisting spiritual beliefs. Both French Canadian Catholics and Native women were viewed negatively by Americans. Politically, they hoped to retain power in the contested territory. For French Canadians, the spread of Maria Monk's sacrilegious book was a slight to their religion and therefore their identities. It is also possible that the accusations of inappropriate contact between a Methodist doctor and Native American wives of French Canadians encouraged Native women to stay away from Methodists in fear that they would be violated.

Patriarchal Colonialism 
The colonial institutions of the fur trade and the Methodist and Catholic missions oppressed colonized people in French Prairie, Oregon. Patriarchal sexual colonialism manifested as policies that allowed for abuse of Native women and intermarriage between fur trappers and Native women. Missions also systematized patriarchal sexual colonialism by repressing Native sexuality and enforcing Western sexual ideals. The Indigenous women wielded "power under" their husbands because they were supposed to be submissive but engaged in alternative forms of domesticity, "power with" their husbands because collaborating with them elevated their social status in the colonial view, and "power from" their husbands due to the benefits they gained from marrying them. Some Native women performed "power over" their husbands and "power under" fur trade law when they would leave abusive husbands, as was the case with Celiast Smith (Peterson-del Mar 1995).

Patriarchal economic colonialism manifested as the exclusion of Native women from the fur trade, the colonists' devaluing of women's jobs, and the enforcement of domesticity-only roles by Christian missions. Native women in the fur trade were usually pushed out of trading positions, but often they negotiated prices and acted with business savvy as advocates for their husbands. Therefore, they held "power with" their husbands and "power under" the fur trade institution. In the French Prairie community, they held "power with" their husbands because they helped on the farms and raised their families. However, many remained economically dependent on the European and Euro-American men (Spencer-Wood 2016).

Patriarchal domestic colonialism is the type of colonialism that the Christian missions most obviously exerted. Christian missionaries believed in the purity of white womanhood and attempted to train Native woman to exemplify Western ideals of domesticity and femininity. 
Indigenous women used "power under" the missions by resisting enforcement of Western domesticity. However, their cooperation with the missions elevated their social statuses. They exercised "power with" missions by following the teachers' instructions and gained "power from" the domesticity education they received.

\section{Discussion and Conclusions}

In this thesis, I have argued that the community of French-Canadian men and Native American women in French Prairie, Oregon acted pragmatically but were constrained by their positioning within a larger colonial setting. I first discussed background information relevant to the lives of people in this community - Nativc communities, religions, the fur trade, disease, and American Expansion. I then argued that American settlement of Oregon Country constitutes colonialism because various imperial institutions systematically displaced Indigenous groups and took over the land. Following my justification of early settling of Oregon as a form of colonialism, I introduced the models of agency borrowed from Nassaney (2019) and Spencer-Wood (2016) that I used to explain the French-Prairie community's actions. Lastly, I explored the community's interactions with the Methodist and Catholic missions within my established framework of constrained pragmatism, focusing on the Indigenous women's choices within the patriarchal colonialism that they experienced.

Between 1830 to 1840 , constraints placed by the colonial institutions of the fur trade and Christian missions influenced how French Prairie community members made decisions. Their agency was their own, as is evidenced by the independent desire for a Catholic presence in their community (Jetté 2007, 2015) but was restricted by the overarching systems of oppression. 
While their actions seemed somewhat contradictory, viewing them as pragmatic choices made within the confines of patriarchal colonialism illuminates why they eventually snubbed the Methodist missionaries with whom they had originally cooperated. Especially with Indigenous women, this practice of viewing agency as pragmatic but also within a larger system of patriarchal colonialism is important in doing their stories justice. Even today, Indigenous women are often reduced to sexually available cultural brokers. Hopefully, studies such as these respect that Indigenous women suffered and still suffer under colonial rule and make decisions to survive but also retain their Indigeneity and power.

\section{References}

Barman, Jean

2014 French Canadians, Furs, and Indigenous Women in the Making of the Pacific Northwest. UBC Press, Vancouver, BC.

Crenshaw, Kimberlé

1989 Demarginalizing the Intersection of Race and Sex: A Black Feminist Critique of Antidiscrimination Doctrine, Feminist Theory and Antiracist Politics. University of Chicago Legal Forum 1989(1):8.

Jetté, Melinda Marie

2007 "We Have Allmost Every Religion but Our Own”: French-Indian Community Initiatives and Social Relations in French Prairie, Oregon, 1834-1837. Oregon Historical Quarterly. 108(2):222-245. 
2015 At the Hearth of the Crossed Races: A French-Indian Community in 19th-century

Oregon, 1812-1859. OSU Press, Corvallis, OR.

Monk, Maria

1836 Awful disclosures of Maria Monk, as exhibited in a narrative of her sufferings during a residence of five years as a novice, and two years as a black nun, in the Hôtel Dieu nunnery at Montreal. Published for the Trade, London.

Nassaney, Michael S.

2019 Cultural Identity and Materiality at French Fort St. Joseph (20BE23), Niles, Michigan. Historical Archaeology 53(1):56-72.

O’Hara, Edwin V.

1917 Catholic Pioneers of the Oregon Country. The Catholic Historical Review 3(2):187-201. Olson, Jonathan W.

2014 Apostles of Commerce: The Fur Trade in the Colonial Northwest and the Formation of a Hemispheric Religious Economy, 1807-1859. Doctoral Dissertation, Department of Religion, Florida State University, Tallahassee, FL.

Peterson-del Mar, David

1995 Intermarriage and Agency: A Chinookan Case Study. Ethnohistory 42(1):1-30.

Spencer-Wood, Suzanne M.

2016 Feminist Theorizing of Patriarchal Colonialism, Power Dynamics, and Social Agency Materialized in Colonial Institutions. International Journal of Historical Archaeology 20(3):477-491.

Thomas, David C. 
1993 Religion in the far West: Oregon's Willamette Valley, 1830-1850. Doctoral Dissertation, Department of History, Ohio State University, Columbus, $\mathrm{OH}$.

Van Kirk, Sylvia

2002 From "Marrying-In" to "Marrying-Out": Changing Patterns of

Aboriginal/Non-Aboriginal Marriage in Colonial Canada. Frontiers: A Journal of Women

Studies 23(3):1-11.

Vibert, Elizabeth

1995 "The Natives Were Strong to Live": Reinterpreting Early-19th-century Prophetic

Movements in the Columbia Plateau. Ethnohistory 42(2):197-229.

Whaley, Gray H.

2005 Oregon, Ilahee, and the Empire Republic: A Case Study of American Colonialism,

1843-1858. Western Historical Quarterly 36(2):157-178.

2006 "Trophies" for God: native mortality, racial ideology, and the Methodist Mission of lower

Oregon, 1834-1844. Oregon Historical Society 107(1):6-35.

2010 Oregon and the Collapse of Illahee. University of North Carolina Press. 